\title{
Short communication: System of wheat intensification in farmers' field of Sindhuli, Nepal
}

\author{
D Adhikari \\ District Agriculture Development Office, Sindhuli, Nepal
}

\begin{abstract}
Food requirement is increasing day by day whereas production of food is not sufficient or decreasing due to various factors. In Nepal, wheat is third major cereal crop after rice and maize both in area and production, and can be grown all over the country successfully during winter season. A study was conducted during 2011/12 to determine the performance of System of Wheat Intensification (SWI) at farmers' field of Bhimasthan, Sindhuli, Nepal. Germinated seed of wheat variety Bhirkuti was shown on $6^{\text {th }}$ Dec 2011 in the spacing 20x20 cm. Average tiller number and number of effective tillers were 25 and 21 respectively. Average plant height was $61.5 \mathrm{~cm}$. at 65 Days after Sowing. The results of this study showed that plant height, numbers of tillers/ hill, number of productive tillers, panicle length, and production were found higher in SWI method. Yield of wheat variety (Bhirkuti) was found 2.6, 2.4 and $2.3 \mathrm{~kg} / 4 \mathrm{~m} 2$ in SWI, Line sown and broadcast practices, respectively.
\end{abstract}

Key words : wheat, system of wheat intensification (SWI)

\section{Introduction}

Wheat is third ranked cereal crop after rice and maize in Nepal. It is generally grown as winter crop after rice. The total area of wheat is 767499 hectares and production is 1745811 metric tons (mt) with the productivity of $2.27 \mathrm{mt} / \mathrm{ha}$. (MoAC. 2011), which is very low as compared to developed countries (6-7 mt./ha.). Farmers make their own bread and other food items from the wheat as well as sell of it. Wheat cultivation in Nepal is done by traditional method. Broadcasting of seed is common planting method of wheat. In present situation, there is great scope to increase productivity of wheat for food security.

The System of Wheat Intensification, or SWI, is an adaptation of techniques used in the System of Rice Intensification (SRI) which was developed by Henri de Laulanie in Madagascar in the early 1980s. SRI is successfully practiced in over 35 countries, and gave increased paddy yields of 66$87 \%$ (Styger and Ibrahim, 2009). This methodology of wheat cultivation can increase yield by two to three times through some improvements in crop management factors. This technology was already evaluated and demonstrated in some countries in the world including India. System of Wheat Intensification (SWI) intervention had increased the productivity of wheat by more than 2 times (Uphoff et. al., 2011). In 2010/11 SWI was tried in Kailali and some district of western Nepal. Though, no work has been taken up to assess the SWI practice in Sindhuli as yet. Hence, a study was conducted to determine the performance of SWI practice in Nepal.

The System of Wheat Intensification (SWI) was tested first time by Farmers in Goundam and Dire, Timbuktu, Mali in 2009. In 2008, some first trials with SWI were initiated, comparing transplanting of young wheat seedlings (with wide spacing, small but regular applications of water, increased 
organic matter, etc.) with direct-seeding and with controls (traditional broadcasting of seed to establish the crop. In this area, given the heat and wind of the winter season which cause desiccation in plants, direct extrapolation of SRI methods to wheat in this area, i.e. transplanting young seedlings, produced poorer results than conventional practice. However, a direct-seeded version of SWI gave $13 \%$ higher yield, with $30-40 \%$ less labor. The productivity of labor with this method (yield per hour of labor input) went up by $75 \%$, and $25-30 \%$ less water was required.

Table 1. Yield and yield parameters in system of wheat intensification (SWI) in Goundam and Dire, Timbuktu, Mali

\begin{tabular}{lcccc}
\hline Parameters & Units & $\begin{array}{c}\text { SWI } \\
\text { Direct Seeded }\end{array}$ & $\begin{array}{c}\text { SWI } \\
\text { Transplanted }\end{array}$ & $\begin{array}{c}\text { Control } \\
\text { Broadcasting }\end{array}$ \\
\hline Yield & Mt/ha & 2.22 & 1.4 & 1.97 \\
Tillers/plant & Number & 18.4 & 13.1 & 3.7 \\
Panicles/plant & Number & 17.7 & 9.9 & 2.7 \\
Panicle length & cm & 10.2 & 8.4 & 4.2 \\
Grains/panicle & Number & 58 & 42 & 35 \\
\hline
\end{tabular}

SWI was promoted by Rajiv Gandhi Mahila Vikas Pariyojana in Uttar Pradesh, Raibareilly district India in 2010 (Table 2).

Table 2. System of wheat intensification (SWI), result of Uttar Pradesh (UP), India

\begin{tabular}{lll}
\hline Parameters & Normal wheat & SWI \\
Method of sowing & broadcasted & single seed sowing (in 8 inches square) \\
Seed rate & $35 \mathrm{~kg} /$ acre & kg/acre \\
No. of tillers & $4-5$ & $25-30$ \\
Panicle length & $4-6 \mathrm{~cm}$ & $12-15 \mathrm{~cm}$ \\
Grains per panicle & $25-30$ & $60-70$ \\
\hline
\end{tabular}

Source. Ramanjaneyulu, GV, 2010

Piloting and scaling up of SWI in JEEViKA / Bihar Rural Livelihoods Project (BRLP) 2008-2011 was launched (Uphoff et. al., 2011). SWI involves modifying the practices like seed rate, sowing of seeds at proper spacing, control of water in the main field, weeding/hoeing to ensure higher ratios of tillers to mother seedling, increased number of effective tillers per hill, enhanced panicle length and bolder grains or in short enhanced yield of wheat. System of Wheat Intensification (SWI) was piloted with 415 smallholders during Rabi 2008-09 in 16 hectares of land. The average yield was 3.7 tons per hectare against the yield of 1.8 tons per hectare through conventional methods in the same area. Based on the success of the pilot, the project has scaled up SWI in the subsequent 2 years with 25235 and 48521 smallholders in Bihar, India.

\section{Materials and methods}

A field experiment was conducted in Sandy loam soil ( $\mathrm{pH} 5.1,0.061 \%$ Total N, Medium $\mathrm{P}_{2} \mathrm{O}_{5}$, $79.23 \mathrm{~kg} \mathrm{ha}^{-1} \mathrm{~K}_{2} \mathrm{O}$ and $1.22 \%$ Organic matter) at Bhimasthan -3 , Kadame, Sindhuli, Nepal during December 2009 to 2012 in Integrated Crop and Water Management Program (ICWMP) Farmer Field School (FSS). The study area is 397 masl. in altitude and the location is $27^{0} 08.730^{\prime} \mathrm{N}$ and $086^{0} 03.795^{\prime} \mathrm{E}$. 
The field was plowed into fine soil and leveling of the field was made properly after incorporation of $10 \mathrm{t}$ Farm yard Manure (FYM)/ha in soil. The plot size was $4 \times 1 \mathrm{~m}$. Recommended dose of fertilizers were applied at the rate of $100.50 .25 \mathrm{Kg} \mathrm{N}$. $\mathrm{P}_{2} \mathrm{O}_{5} . \mathrm{K}_{2} \mathrm{O} /$ ha and mixed with soil. Full dose of FYM, phosphorus $(\mathrm{P})$ and potash $(\mathrm{K})$ and $1 / 3^{\text {rd }}$ dose of nitrogen $(\mathrm{N})$ were applied as basal while the other $2 / 3$ doses of $\mathrm{N}$ were applied as top dressing in two split doses. Selection of quality seed was done. The germinated seed of wheat variety Bhirkuti was sown on $6^{\text {th }}$ Dec., 2011 in the spacing $20 \times 20 \mathrm{~cm}$. Irrigation was provided during Crown Root Initiation (CRI), tillering and booting stage. Top dressing of $2 / 3^{\text {rd }} \mathrm{N}$ (urea) was done during CRI and booting stage before irrigation. Weeding was done manually.

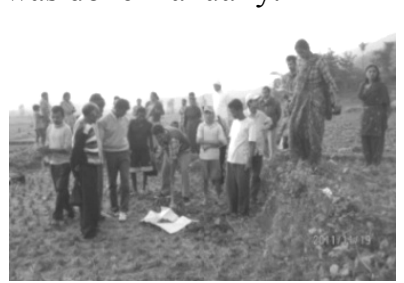

Soil sampling

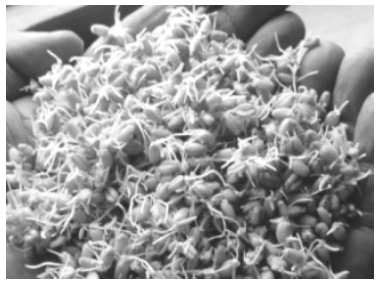

Germinated seeds

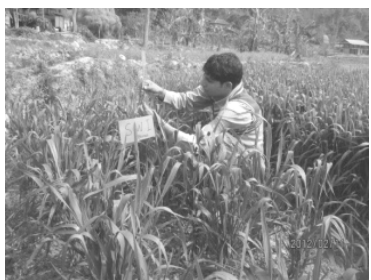

Data recording

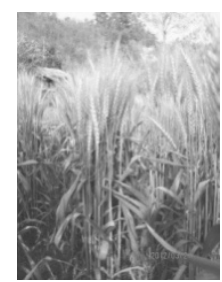

SWI

Visual observations of growth of wheat plant were done and data were recorded on tiller number, plant height, and number of productive tillers, panicle length and yield.

\section{Result and discussion}

The tiller numbers and plant height was found higher in System of Wheat intensification (SWI) i.e. 25 and 61.4 as compared to farmers' practice. The data showed that the average tiller numbers and plant height in conventional broadcasted were lower (2.6 to 3.4) than SWI (25) (not presented).

Average number of effective tillers per hill was found higher in SWI i. e. 21.4 Whereas, 1.7 and 2.3 effective tillers were recorded in conventional broadcasted and line sown methods respectively (not shown). ATMA project on SWI had also found similar result (ATMA, 2008). This might be due to sowing of germinated seeds, and wider spacing in line. Similar results were found in SWI practice reported different countries of world.

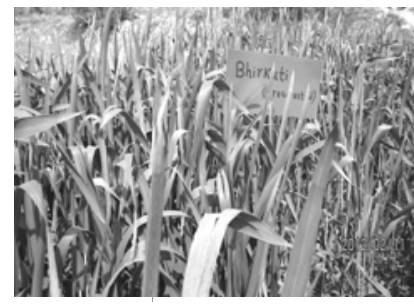

Photo 1. Broadcasted

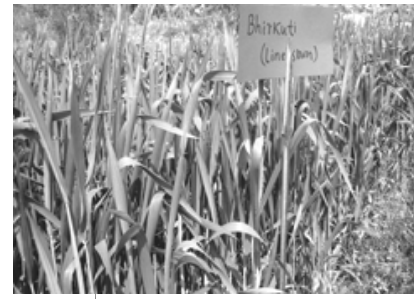

Photo 2. Line sown

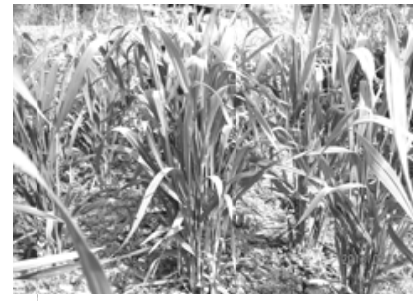

Photo 3. SWI

The panicle length of wheat was found different $(15 \mathrm{~cm}$ and $12 \mathrm{~cm}$. respectively in SWI and conventional broadcasting methods) photo 1,2 and 3). Yield of wheat variety (Bhirkuti) was found 2.6, 2.4 and $2.3 \mathrm{~kg} / 4 \mathrm{~m} 2$ in SWI, Line sown and broadcasted practices respectively (Table 3). 
Table 3. Wheat yield in different methods of sowing in Sindhuli, Nepal

\begin{tabular}{lcc}
\hline Method & Area $^{2}$ & Production $(\mathrm{Kg})$. \\
\hline Broadcast & 4 & 2.3 \\
Line sown & 4 & 2.4 \\
SWI & 4 & 2.6 \\
\hline
\end{tabular}

\section{References}

ATMA. 2008. Assessment, refinement and validation of technology through SWI in Nalanda.

Ramanjaneyulu, G V. 2010. SWI promoted by Rajiv Gandhi Mahila Vikas Pariyojana in Uttar Pradesh, Raibareilly dist. India. 2010.

Styger, E and H Ibrahim. 2009. The System of Wheat Intensification (SWI) First Time Testing by Farmers in Goundam and Dire, Timbuktu, Mali 2009. July 7, 2009.

MoAC. 2011. Statistical Information on Nepalese Agriculture. 2009/2010 (2066/067). Ministry of Agriculture and Co-operatives. Agri-Business Promotion and Statistics Division. Singha Durbar, Kathmandu, Nepal.

Uphoff, NT, Marguerite, Jyoti Devi, D Behera, A K Verma and BJ Pandian. 2011.

National colloquium on system of crop intensification (sci). Field immersion of system of crop intensification (SCI) on 28/02/2011. 